\title{
Anion Dependent Self-assembly; Formation of an Octanuclear Assembly by Templation with the Selenite Dianion.
}

\author{
Christopher J. Clemett, Robert A. Faulkner, Gary Midgley, Christopher Slater and Craig R. Rice* \\ Department of Chemical Sciences, University of Huddersfield, Huddersfield, United Kingdom, HD1 3DH. E-mail: \\ c.r.rice@hud.ac.uk.
}

\begin{abstract}
.
The tripodal ligand $\mathrm{L}$ forms a trinuclear assembly $\left[\mathrm{L}_{2} \mathrm{Cu}_{3}\right]^{6+}$ in which large and unsymmetrical anions are encapsulated, with the X-ray structures of $\left[\mathrm{L}_{2} \mathrm{Cu}_{3}\left(\mathrm{SeO}_{4}\right)\right]^{4+}$ and $\left[\mathrm{L}_{2} \mathrm{Cu}_{3}\left(\mathrm{~S}_{2} \mathrm{O}_{3}\right)\right]^{4+}$ reported. In the presence of the trigonal pyramidal $\mathrm{SeO}_{3}{ }^{2-}$ anion, both a trinuclear $\left[\mathrm{L}_{2} \mathrm{Cu}_{3}\left(\mathrm{SeO}_{3}\right)\right]^{4+}$ and an octametallic assembly $\left[\mathrm{L}_{4} \mathrm{Cu}_{8}\left(\mathrm{SeO}_{3}\right)_{4}\right]^{8+}$ are formed and are analysed by X-ray crustallography. The formation of the octanuclear species is a consequence of maximising both the $-\mathrm{NH}^{\cdots} \cdot \mathrm{SeO}_{3}{ }^{2-}$ interactions and the $\mathrm{Cu}^{2+}$ coordination bonds.
\end{abstract}

\section{Introduction}

The formation of metallosupramolecular assemblies is reliant upon both the coordination preference of metal ions and the disposition and nature of the binding sites within a ligand strand. Controlling these factors allows the construction of multi-metallic helicates, mesocates, circular helicates, cages and other assemblies. ${ }^{1-4}$ More often than not these assemblies are cationic and the associated anions generally do not affect the assembly, especially when weakly interacting anions are employed (e.g. triflate, perchlorate and tetrafluoroborate). However, it is becoming increasingly apparent that in cases where the ligand can interact with anions (usually via hydrogen bond donor units) these interactions can be used to influence aspects of the overall assembly. ${ }^{5}$ One of the earliest examples of this is Lehn's ethylene-bridged tris-bipyridine ligand which, upon reaction with $\mathrm{FeCl}_{2}$, forms the pentanuclear circular helicate with chloride acting as a central template. Under the same conditions, but in the presence of sulfate, a hexanuclear circular helicate is formed as a consequence of templation with the larger anion. ${ }^{6}$ The actual nature of an assembly can also be controlled in this manner with Liu demonstrating that a flexible amide-containing ligand forms a hexanuclear circular helicate with $\mathrm{La}\left(\mathrm{ClO}_{4}\right)_{3}$ but forms a quadruple-stranded tetranuclear helicate with $\mathrm{La}\left(\mathrm{NO}_{3}\right)_{3}{ }^{7}$ Dunbar and co-workers showed that anions could direct the assembly process of a bis-bidentate tetrazinebridged ligand, which formed molecular squares with $\mathrm{Ni}^{2+}$ and either $\mathrm{ClO}_{4}{ }^{-}$or $\mathrm{BF}_{4}{ }^{-}$but molecular pentagons in the presence of the larger $\mathrm{SbF}_{6}{ }^{-}$anions. ${ }^{8}$

Anions can also have more subtle effects and can alter the stereochemistry of the resultant assembly. For example, $\mathrm{Wu}$ et al. demonstrated that a bis-bipyridine ligand, separated by an imidazolium bridge, forms a dinuclear triple helicate in the presence of small anions $\left(\mathrm{NO}_{3}{ }^{-}\right.$and $\left.\mathrm{Br}^{-}\right)$but a dinuclear triple mesocate with larger anions $\left(\mathrm{BF}_{4}{ }^{-}, \mathrm{SO}_{4}{ }^{2-}\right.$ and $\left.\mathrm{ClO}_{4}^{-}\right) .{ }^{9}$ In a similar fashion Gan et al. showed that the helicity of a quadruply stranded helicate $\left[\mathrm{M}_{2} \mathrm{~L}_{4}\right]^{4+}$ can be tuned by the encapsulation of anions. The anionic species are incorporated within the metallasupramolecular host by interaction with amide units on the ligand strand and the resulting binding affects the twist of the assembly. ${ }^{10}$

Recently we have made a series of ligand strands containing amine units to explore the symbiotic effect of the metal ion, ligand strand and anion on the self-assembly process. For example, a bis-pyridylthiazole ligand separated by a 1,3-phenylenediamine unit forms a dinuclear double helicate with $\mathrm{Cu}^{2+}$ and the resultant assembly interacts with both $\mathrm{BF}_{4}{ }^{-}$and $\mathrm{ClO}_{4}{ }^{-}$anions. Addition of half an equivalent of dihydrogen phosphate per complex results in incorporation of this anion within the assembly forming an unsaturated dinuclear double helicate (as the phosphate coordinates the 
metal ions). Addition of a further half equivalent of dihydrogen phosphate results in the assembly rearranging to a trinuclear circular helicate which then forms dimers via hydrogen bonding between the phosphate units. ${ }^{11}$

As anions are important species in both biological and environmental systems, the ability of self-assembled systems to interact with anionic guests has particularly important applications. ${ }^{12}$ These assembled host species may have applications in the detection, separation and sequestration of biologically and environmentally important anions. For example, Leigh and co-workers have demonstrated that a self-assembled molecular pentafoil knot binds halide anions in there central cavities through electrostatic and $\mathrm{CH}^{\cdots} \mathrm{X}^{-}$hydrogen-bonding interactions. The binding is up to $3.6 \times$ $10^{10} \mathrm{M}^{-1}$, making these topologically complex host molecules comparable to the affinity of chloride ion to silver salts. ${ }^{13}$ Rice et al. have shown that the tripodal ligand L, which contains three bidentate pyridyl-thiazole units separated by a tris(2-aminoethyl)amine spacer, forms a trinuclear cryptand with $\mathrm{Cu}^{2+}\left(\right.$ e.g. $\left.\left[\mathrm{L}_{2} \mathrm{Cu}_{3}\right]^{6+}\right)$. These assembles can bind a large variety of spherical, trigonal planar, tetrahedral and octahedral anions and the strength of the binding of the anions is such that the complex can efficiently remove phosphate anions from water, reducing levels from 1000 to $<0.1$ ppm. $^{14}$

In this work we demonstrate that the tripodal ligand $\mathrm{L}$ forms trinuclear assemblies with large and unsymmetrical anions $\left(\mathrm{SeO}_{4}{ }^{2-}\right.$ and $\left.\mathrm{S}_{2} \mathrm{O}_{3}{ }^{2-}\right)$ but in the presence of the trigonal pyramidal $\mathrm{SeO}_{3}{ }^{2-}$ anion an octametallic assembly $\left[\mathrm{L}_{4} \mathrm{Cu}_{8}\left(\mathrm{SeO}_{3}\right)_{4}\right]^{8+}$ is formed. The formation of the octanuclear species is a consequence of maximising both the $\mathrm{NH} \cdots \mathrm{SeO}_{3}{ }^{2-}$ interactions and the $\mathrm{Cu}^{2+}$ coordination bonds.

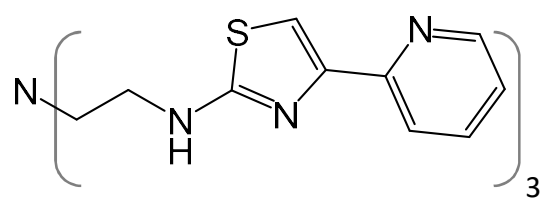

Fig. 1. Tripodal ligand L

\section{Materials and measurements.}

\subsection{General.}

Chemicals were purchased and used without further purification apart from ligand L which was prepared by a previously reported method. ${ }^{14}{ }^{1} \mathrm{H}$ NMR spectra were recorded either on a $400 \mathrm{MHz}$ Bruker Advance DP X400 or on a $500 \mathrm{MHz}$ Bruker Advance 500. Mass spectra were obtained on a Bruker MicroTOF-q LC mass spectrometer.

\subsection{Synthesis of complexes.}

$\left[\mathrm{L}_{2} \mathrm{Cu}_{3}\left(\mathrm{SeO}_{4}\right)\right]\left(\mathrm{BF}_{4}\right)_{4}$. The ligand $\mathrm{L}(5 \mathrm{mgs}, 8 \mathrm{mmol})$ and $\mathrm{Cu}\left(\mathrm{BF}_{4}\right)_{2} \cdot 6 \mathrm{H}_{2} \mathrm{O}(4.1 \mathrm{mgs}, 12 \mathrm{mmol})$ were dissolved in acetone $(0.25 \mathrm{ml})$ to give a light blue coloured solution. To this was added $\mathrm{Na}_{2} \mathrm{SeO}_{4}(0.75 \mathrm{mg}, 4 \mathrm{mmol})$ as a solution in water $(0.25 \mathrm{ml})$ and the reaction sonicated until all the reactants had dissolved, adding more acetone or water if necessary. The solution was then left to slowly evaporate giving green crystals which were isolated by filtration and dried under vacuum; yield $=6.7 \mathrm{mgs}(87 \%) .\left(\mathrm{C}_{30} \mathrm{H}_{30} \mathrm{~N}_{10} \mathrm{~S}_{3}\right)_{2} \mathrm{Cu}_{3}\left(\mathrm{SeO}_{4}\right)\left(\mathrm{BF}_{4}\right)_{4} \cdot 4 \mathrm{H}_{2} \mathrm{O}$ found $\mathrm{C} 35.8, \mathrm{H} 3.2, \mathrm{~N} 13.9 \%$ calculated 35.9, H 3.4, N 14.0\%. ESI-MS $m / z 1848\left\{\left[\mathrm{~L}_{2} \mathrm{Cu}_{3}\left(\mathrm{SeO}_{4}\right)\right]\left(\mathrm{BF}_{4}\right)_{3}\right\}^{+}$.

$\left[\mathrm{L}_{2} \mathrm{Cu}_{3}\left(\mathrm{~S}_{2} \mathrm{O}_{3}\right)\right]\left(\mathrm{BF}_{4}\right)_{4}$. The ligand $\mathrm{L}(5 \mathrm{mgs}, 8 \mathrm{mmol})$ and $\mathrm{Cu}\left(\mathrm{BF}_{4}\right)_{2} \cdot 6 \mathrm{H}_{2} \mathrm{O}(4.1 \mathrm{mgs}, 12 \mathrm{mmol})$ were dissolved in $\mathrm{MeCN}$ $(0.25 \mathrm{ml})$ to give a light blue coloured solution. To this was added $\mathrm{Na}_{2} \mathrm{~S}_{2} \mathrm{O}_{3}(0.63 \mathrm{mg}, 4 \mathrm{mmol})$ as a solution in water $(0.25 \mathrm{ml})$ and the reaction sonicated until all the reactants had dissolved, adding more MeCN or water if necessary. The solution was then left to slowly evaporate giving brown crystals which were isolated by filtration and dried under

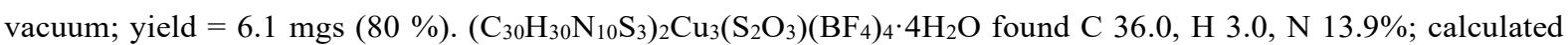
36.5, H 3.5, N 14.2\%. ESI-MS m/z $1816\left\{\left[\mathrm{~L}_{2} \mathrm{Cu}_{3}\left(\mathrm{~S}_{2} \mathrm{O}_{3}\right)\right]\left(\mathrm{BF}_{4}\right)_{3}\right\}^{+}, m / z 1728\left\{\left[\mathrm{~L}(\mathrm{~L}-\mathrm{H}) \mathrm{Cu}_{3}\left(\mathrm{~S}_{2} \mathrm{O}_{3}\right)\right]\left(\mathrm{BF}_{4}\right)_{2}\right\}^{+}$and 953 $\left\{\left[\mathrm{LCu}_{2}\left(\mathrm{~S}_{2} \mathrm{O}_{3}\right)\right]\left(\mathrm{BF}_{4}\right)\right\}^{+}$. 
$\left[\mathrm{L}_{2} \mathrm{Cu}_{3}\left(\mathrm{SeO}_{3}\right)\right]\left(\mathrm{BF}_{4}\right)_{4}$. The ligand $\mathrm{L}(5 \mathrm{mgs}, 8 \mathrm{mmol})$ and $\mathrm{Cu}\left(\mathrm{BF}_{4}\right)_{2} \cdot 6 \mathrm{H}_{2} \mathrm{O}(4.1 \mathrm{mgs}, 12 \mathrm{mmol})$ were dissolved in $\mathrm{MeCN}(0.25 \mathrm{ml})$ to give a light blue coloured solution. To this was added $\mathrm{Na}_{2} \mathrm{SeO}_{3}(0.70 \mathrm{mg}, 4 \mathrm{mmol})$ as a solution in water $(0.25 \mathrm{ml})$ and the reaction sonicated until all the reactants had dissolved, adding more $\mathrm{MeCN}$ or water if necessary. The solution was then left to slowly evaporate giving a mixture of light green and dark green crystals (see text).

$\left[\mathrm{L}_{4} \mathrm{Cu}_{8}\left(\mathrm{SeO}_{3}\right)_{4}\right]\left(\mathrm{BF}_{4}\right)_{8}$. The ligand $\mathrm{L}(5 \mathrm{mgs}, 8 \mathrm{mmol})$ and $\mathrm{Cu}\left(\mathrm{BF}_{4}\right)_{2} \cdot 6 \mathrm{H}_{2} \mathrm{O}(5.5 \mathrm{mgs}, 16 \mathrm{mmol})$ were dissolved in $\mathrm{MeCN}(0.25 \mathrm{ml})$ to give a light blue coloured solution. To this was added $\mathrm{Na}_{2} \mathrm{SeO}_{3}(0.70 \mathrm{mg}, 4 \mathrm{mmol})$ as a solution in water $(0.25 \mathrm{ml})$ and the reaction sonicated until all the reactants had dissolved, adding more $\mathrm{MeCN}$ or water if necessary. The solution was then left to slowly evaporate giving dark green crystals which were isolated by filtration and dried under vacuum; yield $=6.7 \mathrm{mgs}(80 \%)$. $\left(\mathrm{C}_{30} \mathrm{H}_{30} \mathrm{~N}_{10} \mathrm{~S}_{3}\right)_{4} \mathrm{Cu}_{8}\left(\mathrm{SeO}_{3}\right)_{4}\left(\mathrm{BF}_{4}\right)_{8} \cdot 6 \mathrm{H}_{2} \mathrm{O}$ found $\mathrm{C} 32.8, \mathrm{H} 2.9, \mathrm{~N}$ 13.3\%; calculated 33.3, H 3.1, N $13.0 \%$. ESI-MS m/z $1832\left\{\left[\mathrm{~L}_{2} \mathrm{Cu}_{3}\left(\mathrm{SeO}_{3}\right)\right]\left(\mathrm{BF}_{4}\right)_{3}\right\}^{+}, 967\left\{\left[\mathrm{LCu}_{2}\left(\mathrm{SeO}_{3}\right)\right]\left(\mathrm{BF}_{4}\right)\right\}^{+}, 879$ $\left\{\left[(\mathrm{L}-\mathrm{H}) \mathrm{Cu}_{2}\left(\mathrm{SeO}_{3}\right)\right]\right\}^{+}$and $688\{[(\mathrm{~L}-\mathrm{H}) \mathrm{Cu}]\}^{+}$.

\subsection{Single-Crystal X-ray crystallography}

Single crystal X-ray diffraction data was collected at 150(2) K on a Venture diffractometer equipped with a Mo-I $\mu \mathrm{S}$ source and a cold stream of $\mathrm{N}_{2}$ gas. Solutions were generated by conventional heavy atom Patterson or direct methods and refined by full-matrix least squares on all $F^{2}$ data, using SHELXS-97 and SHELXL software respectively. Absorption corrections were applied based on multiple and symmetry equivalent measurements using SADABS.

Crystal data for $\left[\mathrm{L}_{2} \mathrm{Cu}_{3}\left(\mathrm{SeO}_{4}\right)\right]\left(\mathrm{BF}_{4}\right)_{4}: M=1847.72$, monoclinic $C 2 / c, a=28.4930(16), b=20.8749(13), c=$ $33.4848(17) \AA, \beta=114.309(2)^{\circ} V=18150.6(18) \mathrm{A}^{3}, Z=8, T=150 \mathrm{~K}$. A total of 94865 reflections were collected with 22428 independent reflections $\left(R_{i n t}=0.0726\right)$. The final $R_{l}$ values were $0.0790(I>2 \sigma(I))$. The final $w R\left(F^{2}\right)$ values were $0.2138(I>2 \sigma(I))$. The final $R_{l}$ values were 0.1466 (all data). The final $w R\left(F^{2}\right)$ were 0.2662 (all data). The goodness of fit on $F^{2}$ was 1.0763, largest peak and hole 3.1463 and $-1.4749 \mathrm{eA}^{-3}$. CCDC 1957675. The crystal contained a disordered tetrafluoroborate anion for which the fluorine atoms were modelled in two positions using the $P A R T$ instruction. The anions behaved poorly and the bond lengths had to be restrained using DFIX and SADI in the least squares refinement with some of the anisotropic displacement parameters constrained using ISOR. Also contained within the structure was a disordered tetrafluoroborate anion and accompanying solvent molecules, which could not be successfully modelled. The diffuse electron density was removed using the solvent mask facility in Olex2, resulting in voids in the crystal structure. ${ }^{15}$ The solvent mask removed a total of 136 electrons per asymmetric unit which corresponds to one tetrafluoroborate anion and three acetone molecules.

Crystal data for $\left[\mathrm{L}_{2} \mathrm{Cu}_{3}\left(\mathrm{~S}_{2} \mathrm{O}_{3}\right)\right]\left(\mathrm{ClO}_{4}\right)_{4}: M=2118.46$, triclinic $P-1, a=14.656(7), b=15.429(6), c=22.006(8) \AA, \alpha$ $=87.120(13), \beta=75.47(2), \gamma=71.956(16)^{\circ} V=4578(3) \mathrm{A}^{3}, Z=2, T=150 \mathrm{~K}$. A total of 127949 reflections were collected with 24532 independent reflections $\left(R_{\text {int }}=0.0664\right)$. The final $R_{l}$ values were $0.0592(I>2 \sigma(I))$. The final $w R\left(F^{2}\right)$ values were $0.1346(I>2 \sigma(I))$. The final $R_{l}$ values were 0.0990 (all data). The final $w R\left(F^{2}\right)$ were 0.1536 (all data). The goodness of fit on $F^{2}$ was 1.0726, largest peak and hole 2.4183 and $-1.3419 \mathrm{eA}^{-3}$. CCDC 1957676. The crystal contained a disordered perchlorate anion which was modelled in two positions using the PART instruction and the thermal ellipsoids constrained using DELU, SIMU and ISOR. These restraints were also used on the four acetonitrile solvent molecules in the unit cell. Furthermore, the structure contained disorder that could not be satisfactorily modelled and as a result, the diffuse electron density was removed using the solvent mask facility in Olex2. ${ }^{15}$ The solvent mask removed a total of 98 electrons in the unit cell which corresponds to three molecules of acetonitrile and three water molecules in the unit cell. 
Crystal data for $\left[\mathrm{L}_{2} \mathrm{Cu}_{3}\left(\mathrm{SeO}_{3}\right)\right]\left(\mathrm{BF}_{4}\right)_{4}: M=1951.19$, triclinic $P-1, a=15.161(6), b=16.932(6), c=17.887(7) \AA, \alpha$ $=85.721(16), \beta=77.024(18), \gamma=80.146(14)^{\circ} V=4405(3) \mathrm{A}^{3}, Z=2, T=150 \mathrm{~K}$. A total of 95224 reflections were collected with 23591 independent reflections $\left(R_{\text {int }}=0.0823\right)$. The final $R_{l}$ values were $0.0785(I>2 \sigma(I))$. The final $w R\left(F^{2}\right)$ values were $0.2040(I>2 \sigma(I))$. The final $R_{l}$ values were 0.1315 (all data). The final $w R\left(F^{2}\right)$ were 0.2361 (all data). The goodness of fit on $F^{2}$ was 1.0765 , largest peak and hole 2.9130 and -1.2638 eA ${ }^{-3}$. CCDC 1957677. The structure contained two disordered tetrafluoroborate anions which were modelled in two positions using the $P A R T$ instruction and one was restrained using the $S A D I$ and $I S O R$ instructions. The two acetonitrile solvent molecules were poorly defined and the DELU, SIMU and ISOR instructions were required and due to their poor definition, the methyl hydrogen atoms were not added. Furthermore, the structure contained disorder that could not be satisfactorily modelled. As a result the diffuse electron density was removed using the solvent mask facility in Olex2, resulting in voids in the crystal structure. ${ }^{15}$ The solvent mask removed a total of 173 electrons in the unit cell which corresponds to six molecules of acetonitrile and four water molecules in the unit cell.

Crystal data for $\left[\mathrm{L}_{4} \mathrm{Cu}_{8}\left(\mathrm{SeO}_{3}\right)_{4}\right]\left(\mathrm{ClO}_{4}\right)_{8}: M=4088.25$, tetragonal $P-4 n 2, a=18.797(6), c=25.951(8) \AA, V=9170(5)$ $\mathrm{A}^{3}, Z=2, T=150 \mathrm{~K}$. A total of 47003 reflections were collected with 11299 independent reflections $\left(R_{\text {int }}=0.0865\right)$. The final $R_{l}$ values were $0.0757(I>2 \sigma(I))$. The final $w R\left(F^{2}\right)$ values were $0.1811(I>2 \sigma(I))$. The final $R_{l}$ values were 0.1488 (all data). The final $w R\left(F^{2}\right)$ were 0.2147 (all data). The goodness of fit on $F^{2}$ was 1.1714 , largest peak and hole 1.3074 and $-1.0092 \mathrm{eA}^{-3}$. CCDC 1957678. The crystal gave poor diffraction, especially at high angle. As a result, no solvent molecules could be found in the difference Fourier map and the electron density from these was removed using the solvent mask facility in Olex $2 .{ }^{15}$ Also, two perchlorate anions could not be located (assuming all the copper metal ions are divalent, which seems likely). One of the perchlorate anions was also on a special position and could only be modelled poorly. The solvent mask removed a total of 445 electrons in the unit cell which corresponds to two perchlorate anions and sixteen molecules of acetonitrile in the unit cell (four solvent molecules per asymmetric unit).

\section{Results and discussion.}

\subsection{Synthesis and characterisation of $\left[\mathrm{L}_{2} \mathrm{Cu}_{3}\left(\mathrm{SeO}_{4}\right)\right]\left(\mathrm{BF}_{4}\right)_{4}$}

Reaction of the ligand $\mathrm{L}$ with 1.5 equivalents of $\mathrm{Cu}\left(\mathrm{BF}_{4}\right)_{2} \cdot 6 \mathrm{H}_{2} \mathrm{O}$ in aqueous acetone gives a light blue coloured solution which contains the trinuclear assembly $\left[\mathrm{L}_{2} \mathrm{Cu}_{3}\right]\left(\mathrm{BF}_{4}\right)_{6} \cdot{ }^{14}$ Reaction of this assembly with one equivalent of $\mathrm{Na}_{2} \mathrm{SeO}_{4}$ gives a brown solution from which were deposited greenish brown crystals upon slow evaporation. Examination of the crystals by X-ray diffraction showed the expected trinuclear assembly. In the solid state each of the three bidentate pyridyl-thiazole domains on the ligand strand coordinate a different copper metal ion and each metal ion in turn is coordinated by two separate ligands resulting in coordination by a total of four N-donor atoms, two from each ligand (Fig 2). In the centre of the self-assembled species is a cavity which contains an encapsulated $\mathrm{SeO}_{4}{ }^{2-}$ anion giving $\left[\mathrm{L}_{2} \mathrm{Cu}_{3}\left(\mathrm{SeO}_{4}\right)\right]\left(\mathrm{BF}_{4}\right)_{4}$. This single anion is held within the cavity by atal of nine interactions comprising three $\mathrm{Cu}-\mathrm{O}$ coordination bonds and six $-\mathrm{NH} \cdots \mathrm{O}$ hydrogen bonds. Each of the three copper ions coordinate one of the oxygen atoms of the anion and this interaction is supplemented by a $-\mathrm{NH} \cdots \mathrm{O}$ hydrogen bond from the amine units on the ligand chain (Fig 2d). The uncoordinated oxygen atom points upward from the "Cu 3 " core and interacts with the three remaining-NH units. The trinuclear cage and encapsulated selenite anion is also observed in the gas phase with an ion in the ESI-MS at $m / z 1848$ corresponding to $\left\{\left[\mathrm{L}_{2} \mathrm{Cu}_{3}\left(\mathrm{SeO}_{4}\right)\right]\left(\mathrm{BF}_{4}\right)_{3}\right\}^{+}$. 


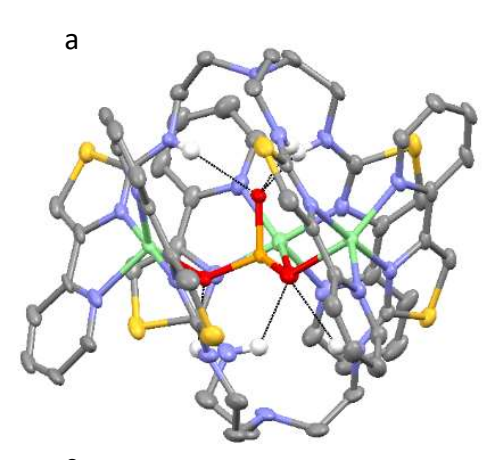

C

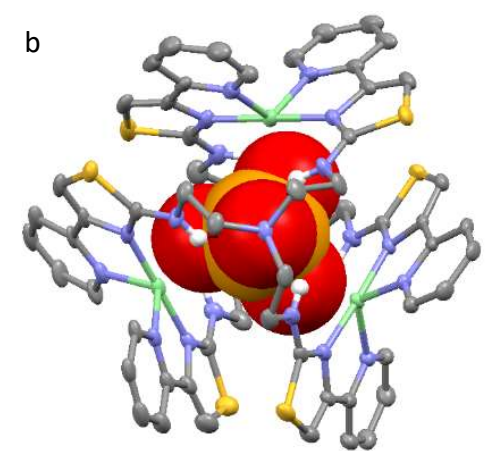

d

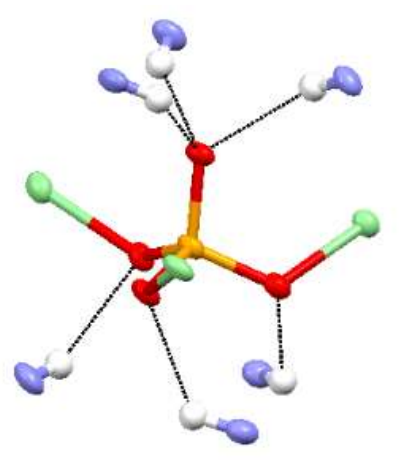

Fig. 2. Single-crystal X-ray structure of $\left[\mathrm{L}_{2} \mathrm{Cu}_{3}\left(\mathrm{SeO}_{4}\right)\right]^{4+}$. Tetrafluoroborate anions are omitted for clarity. Thermal ellipsoids are shown at the 50\% probability level. Colour code: light green, $\mathrm{Cu}^{2+}$; red, O; blue, N; yellow, $\mathrm{S}$; grey, $\mathrm{C}$; white, $\mathrm{H}$ (apart from $2 \mathrm{c}$ where the ligands have been coloured for clarity).

\subsection{Synthesis and characterisation of $\left[\mathrm{L}_{2} \mathrm{Cu}_{3}\left(\mathrm{~S}_{2} \mathrm{O}_{3}\right)\right]\left(B \mathrm{BF}_{4}\right)_{4}$}

Reaction of $\left[\mathrm{L}_{2} \mathrm{Cu}_{3}\right]\left(\mathrm{BF}_{4}\right)_{6}$ with one equivalent of $\mathrm{Na}_{2} \mathrm{~S}_{2} \mathrm{O}_{3}$ in aqueous MeCN gives a brown coloured solution from which crystals were produced upon slow evaporation of the solvent. In the solid-state the trinuclear assembly is formed in an analogous fashion to $\left[\mathrm{L}_{2} \mathrm{Cu}_{3}\left(\mathrm{SeO}_{4}\right)\right]\left(\mathrm{BF}_{4}\right)_{4}$ but encapsulated within the core is a molecule of $\mathrm{S}_{2} \mathrm{O}_{3}{ }^{2-}\left(\mathrm{Fig}^{2}\right.$. 3). The thiosulfate anion coordinates the three $\mathrm{Cu}^{2+}$ ions via two oxygen atoms and one sulfur atom and each of these bonds are supplemented by three - $\mathrm{NH} \cdots$ anion interactions (fig. 3d). The remaining oxygen atom points upward from the " $\mathrm{Cu}_{3}$ " plane and forms three $-\mathrm{NH} \cdots \mathrm{O}$ hydrogen bonding interactions with the ligand amine units. The formation of the $\mathrm{Cu}-\mathrm{S}$ coordination bond, as opposed to the three $-\mathrm{NH} \cdots \mathrm{S}$ hydrogen bonding interactions and three $\mathrm{Cu}-\mathrm{O}$ coordination bonds, can be attributed to the localisation of the negative charge on the sulphur atom which forms the coordination bond with the dicationic copper atom. However, the soft donor/acceptor interaction between sulfur and copper may also play a contributing part. An ion in the ESI-MS at small ion at $m / z 1816$ corresponds to the host guest complex $\left\{\left[\mathrm{L}_{2} \mathrm{Cu}_{3}\left(\mathrm{~S}_{2} \mathrm{O}_{3}\right)\right]\left(\mathrm{BF}_{4}\right)_{3}\right\}^{+}$and is accompanied by fragmentation ions such as $m / z 1728$ and 953 corresponding to $\left\{\left[\mathrm{L}(\mathrm{L}-\mathrm{H}) \mathrm{Cu}_{3}\left(\mathrm{~S}_{2} \mathrm{O}_{3}\right)\right]\left(\mathrm{BF}_{4}\right)_{2}\right\}^{+}$and $\left\{\left[\mathrm{LCu}_{2}\left(\mathrm{~S}_{2} \mathrm{O}_{3}\right)\right]\left(\mathrm{BF}_{4}\right)\right\}^{+}$. 

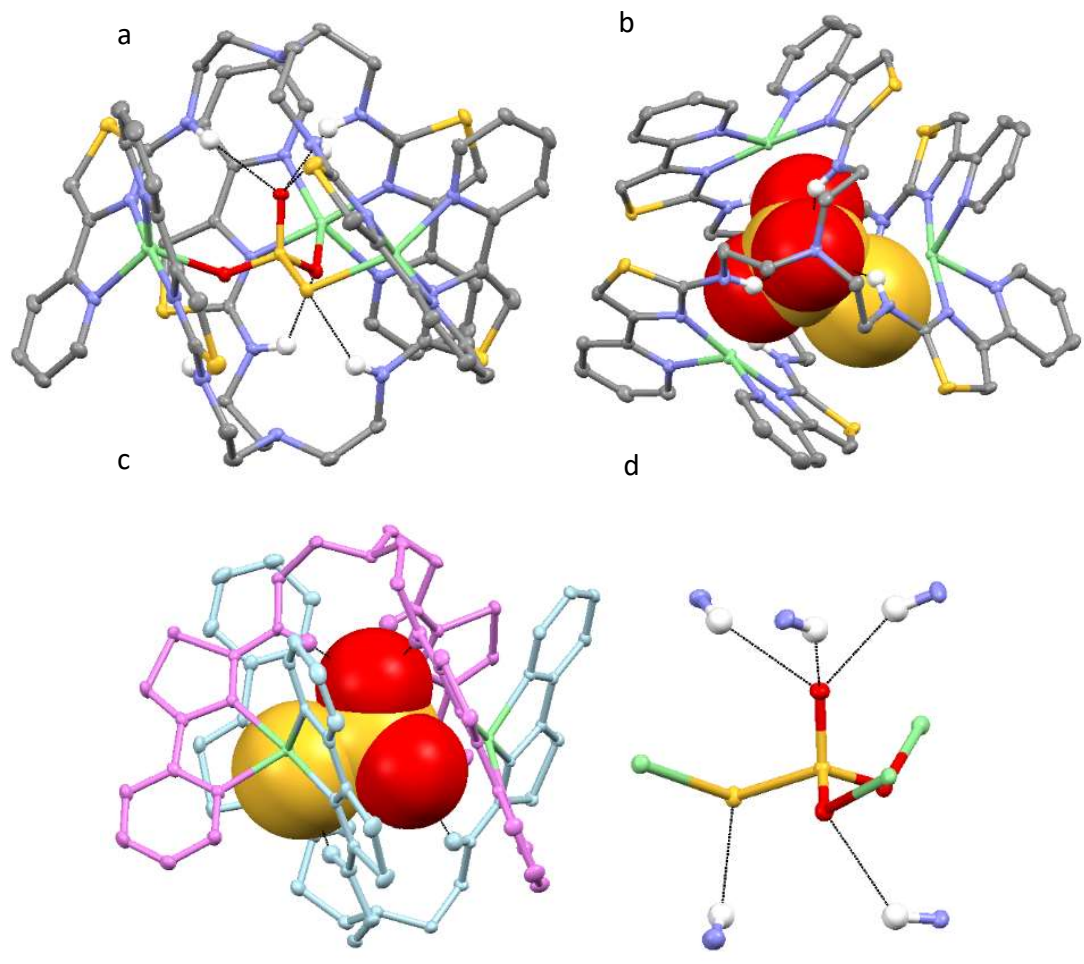

Fig. 3. Single-crystal $\mathrm{X}$-ray structure of $\left[\mathrm{L}_{2} \mathrm{Cu}_{3}\left(\mathrm{~S}_{2} \mathrm{O}_{3}\right)\right]^{4+}$. Perchlorate anions are omitted for clarity. Thermal ellipsoids are shown at the 50\% probability level. Colour code: light green, $\mathrm{Cu}^{2+}$; red, O; blue, N; yellow, $\mathrm{S}$; grey, $\mathrm{C}$; white, $\mathrm{H}$ (apart from $3 \mathrm{c}$ where the ligands have been coloured for clarity)

\subsection{Reaction of $\left[\mathrm{L}_{2} \mathrm{Cu}_{3}\right]^{6+}$ with $\mathrm{SeO}_{3}{ }^{2-}$.}

Reaction of one equivalent of $\mathrm{Na}_{2} \mathrm{SeO}_{3}$ with $\left[\mathrm{L}_{2} \mathrm{Cu}_{3}\right]^{6+}$ in aqueous $\mathrm{MeCN}$ gives a green-coloured solution from which crystals were deposited upon slow evaporation of the solvent. The crystalline mass was comprised of dark green multi-faceted crystals, but also contained one or two lime-green block shaped crystals, which were obviously different from the bulk material. Analysis of the latter via single-crystal X-ray diffraction showed that in the solid-state, the trinuclear assembly is formed as expected and a molecule of $\mathrm{SeO}_{3}{ }^{2-}$ is encapsulated within the core i.e. $\left[\mathrm{L}_{2} \mathrm{Cu}_{3}\right.$ $\left.\left(\mathrm{SeO}_{3}\right)\right]^{4+}$ (Fig. 4). Interestingly, this anion forms two $\mathrm{Cu}-\mathrm{O}$ coordination bonds supplemented again by two $-\mathrm{NH} \cdots \mathrm{O}$ hydrogen bonding interactions and the remaining oxygen atom forming hydrogen bonding interactions with the three amine units above the "Cu3" plane (Fig. 4d). This results in two different coordination environments with two $\mathrm{Cu}^{2+}$ ions adopting a five-coordinate geometry arising from coordination of two bidentate N-donor domains from the ligand and one oxygen atom. The remaining $\mathrm{Cu}^{2+}$ atom is four coordinate, resulting from the coordination of two ligand bidentate units. However, as the oxygen atoms are far too distant, no anion coordination bonds are formed to this metal ion. For the same reason the amine unit closest to the four-coordinate $\mathrm{Cu}^{2+}$ atom is not involved in hydrogen-bonding interaction with the encapsulated anion. It is worth noting that the host could potentially bind the anion via all of the $\mathrm{Cu}^{2+}$ ions, with each of the three metal cations coordinated via the three anion oxygen atoms. 
However, it is clear that in the solid-state the anion coordinates two metal ions and forms three $-\mathrm{NH} \cdots \mathrm{O}$ hydrogen bonds with the three amine units above the $\left\{\mathrm{Cu}_{3}\right\}$ plane in preference to coordinating all the $\mathrm{Cu}^{2+}$ ions.
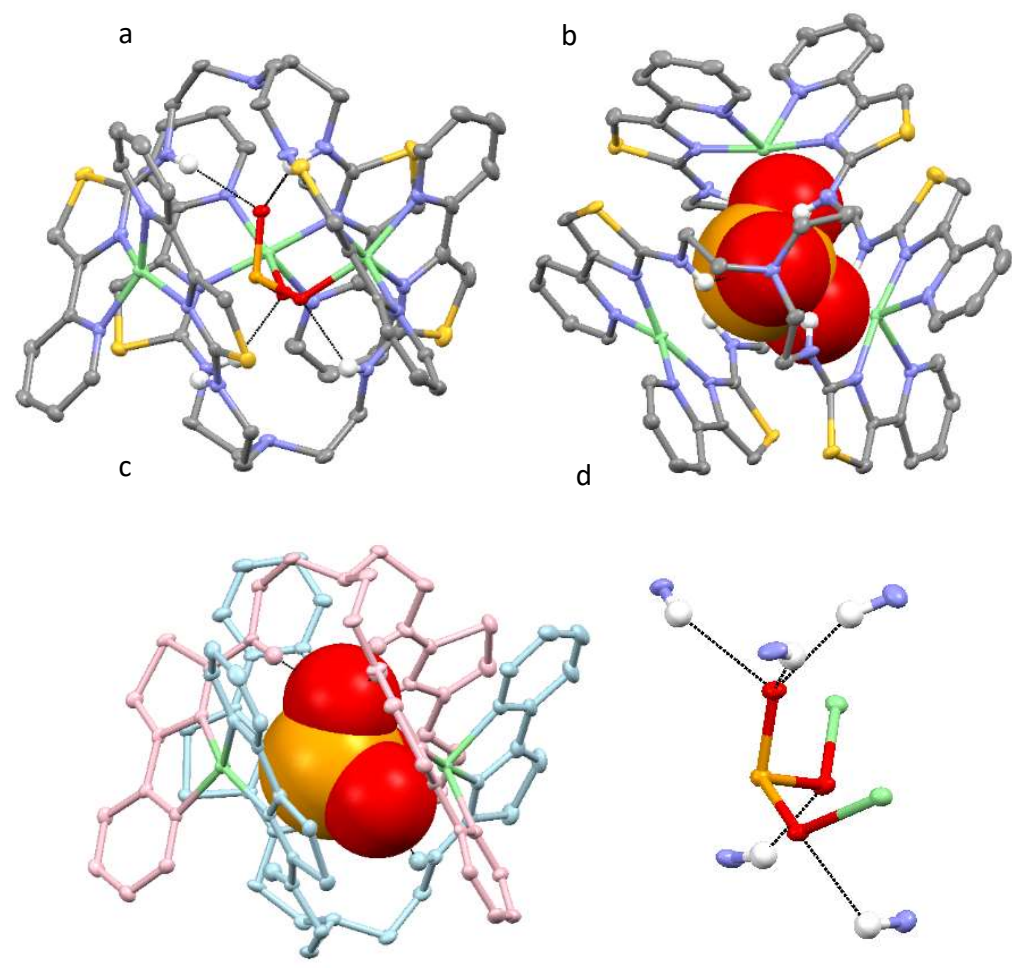

Fig. 4. Single-crystal X-ray structure of $\left[\mathrm{L}_{2} \mathrm{Cu}_{3}\left(\mathrm{SeO}_{3}\right)\right]^{4+}$. Perchlorate anions are omitted for clarity. Thermal ellipsoids are shown at the $50 \%$ probability level. Colour code: light green, $\mathrm{Cu}^{2+}$; dark yellow, Se; red, O; blue, N; yellow, $\mathrm{S}$; grey, $\mathrm{C}$; white, $\mathrm{H}$ (apart from $4 \mathrm{c}$ where the ligands have been coloured for clarity).

Analysis of the more numerous dark-green crystals by single-crystal X-ray diffraction showed a very different specie and solid-state analysis revealed a complex comprised of eight copper metal ions, four ligands and four selenite anions e.g. $\left[\mathrm{L}_{4} \mathrm{Cu}_{8}\left(\mathrm{SeO}_{3}\right)_{4}\right]^{8+}$ (Fig. 5). In the assembly, each of the $\mathrm{Cu}^{2+}$ metal ions are five coordinate but this geometry arises for two different donor sets. One coordination geometry is formed from two bidentate pyridinethiazole domains and an oxygen atom from the selenite anion with the other comprised of one bidentate bipyridinethiazole unit and three oxygen atoms of the anion. One of the selenite oxygen atoms bridges two $\mathrm{Cu}^{2+}$ atoms resulting in a circular arrangement of alternating copper metal ions and selenite anions (Fig. 5d). Each of the amine units form hydrogen bonding interactions with the anion, one of which bridges two oxygen atoms from two different anions (Fig 5e).

The octametallic species is clearly the favoured product in the presence of $\mathrm{SeO}_{3}{ }^{2-}$ and its preference is attributed to the maximising both of the coordination and hydrogen-bonding interactions. In the trinuclear specie $\left[\mathrm{L}_{2} \mathrm{Cu}_{3}\left(\mathrm{SeO}_{3}\right)\right]^{4+}$ only two of the $\mathrm{Cu}^{2+}$ metal ions are five coordinate and one of the $-\mathrm{NH}$ units from each ligand is not involved in any hydrogen bonding with the anion. However, in $\left[\mathrm{L}_{4} \mathrm{Cu}_{8}\left(\mathrm{SeO}_{3}\right)_{4}\right]^{4+}$ all of the $\mathrm{Cu}^{2+}$ anions are five-coordinate arising from different donor sets with all the amine units suitably arranged to act as hydrogen-bond donors (Fig. 5f). It must be both the coordination of the metal centres and the maximising of hydrogen bonding interactions that dictates the formation of the octanuclear species as three 5coordinate metal ions could be accommodated in the $\left[\mathrm{L}_{2} \mathrm{Cu}_{3}\left(\mathrm{SeO}_{3}\right)\right]^{4+}$ structure.

It seems likely that formation of the minor component $\left[\mathrm{L}_{2} \mathrm{Cu}_{3} \mathrm{SeO}_{3}\right]^{4+}$ is a consequence of the stoichiometry of the reaction (i.e. reaction of two equivalents of $\mathbf{L}$, three equivalents of $\mathrm{Cu}^{2+}$ and one equivalent of $\mathrm{SeO}_{3}{ }^{2-}$ ). When the 
stoichiometry is correct for the formation of octametallic species (i.e. one equivalents each of ligand and anion and two equivalents of $\mathrm{Cu}^{2+}$ ) no minor products in the solid-state are observed.
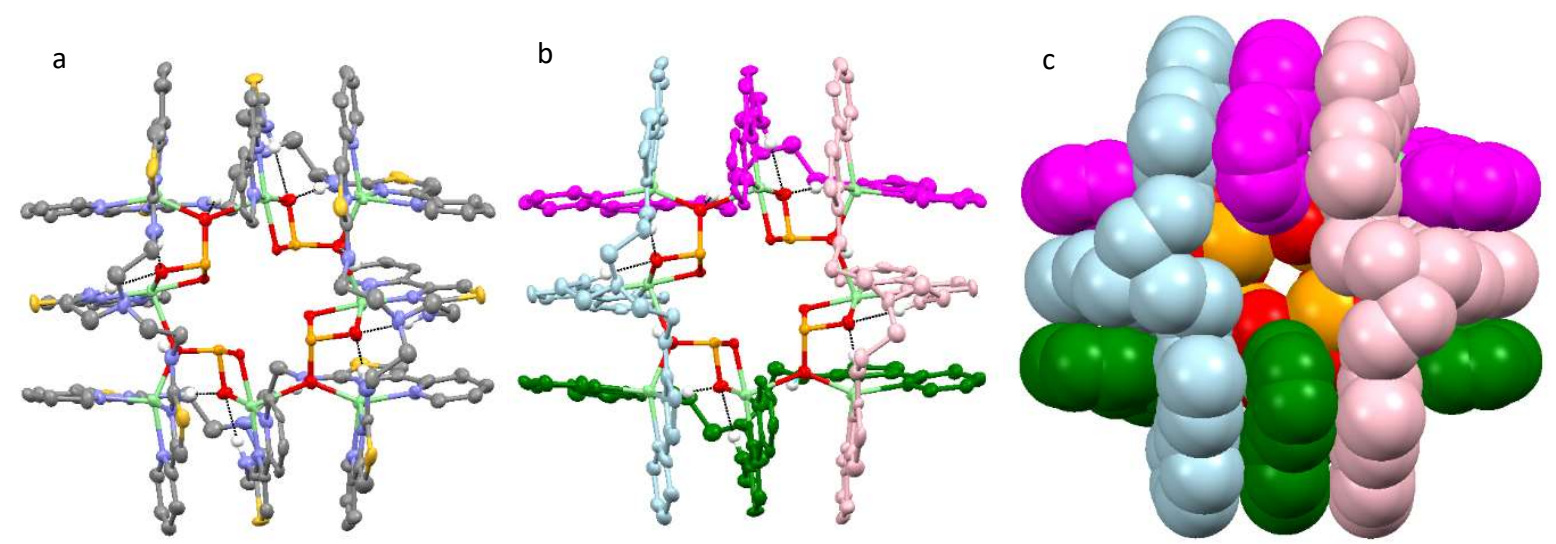

d
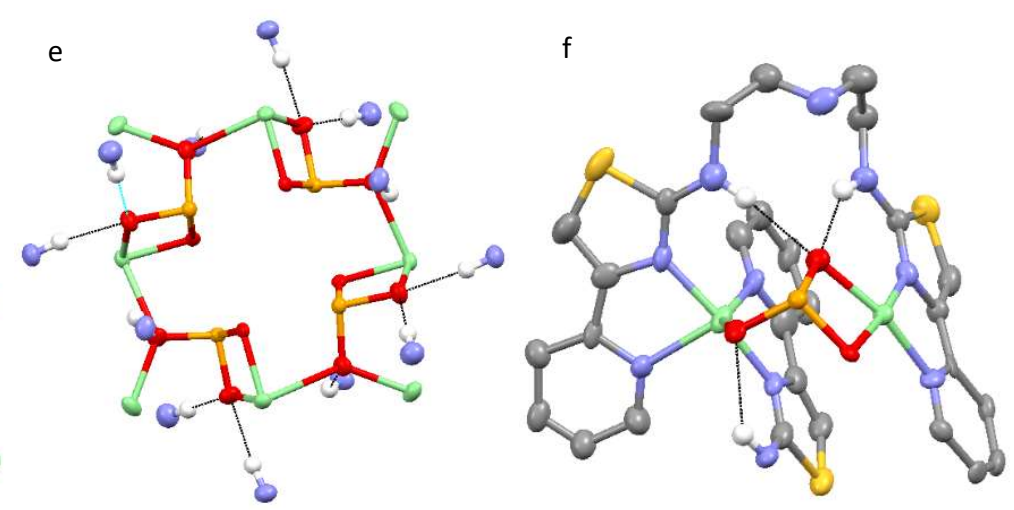

Fig. 5. Single-crystal X-ray structure of $\left[\mathrm{L}_{4} \mathrm{Cu}_{8}\left(\mathrm{SeO}_{3}\right)_{4}\right]^{8+}$. Perchlorate anions are omitted for clarity. Thermal ellipsoids are shown at the $50 \%$ probability level. Colour code: light green, $\mathrm{Cu}^{2+}$; dark yellow, Se; red, O; blue, N; yellow, S; grey, C; white, $\mathrm{H}$ (apart from $5 \mathrm{~b}$ and $\mathrm{c}$ where the ligands have been coloured for clarity). The asymmetric unit contained one ligand, one selenite anion and two copper atoms ( $5 \mathrm{f})$ with the whole assembly generated by symmetry.

Analysis of the complex showed ions at $m / z$ 1832, 967, 879 and 688 corresponding to $\left\{\left[\mathrm{L}_{2} \mathrm{Cu}_{3}\left(\mathrm{SeO}_{3}\right)\right]\left(\mathrm{BF}_{4}\right)_{3}\right\}^{+}$, $\left\{\left[\mathrm{LCu}_{2}\left(\mathrm{SeO}_{3}\right)\right]\left(\mathrm{BF}_{4}\right)\right\}^{+},\left\{\left[(\mathrm{L}-\mathrm{H}) \mathrm{Cu}_{2}\left(\mathrm{SeO}_{3}\right)\right]\right\}^{+}$and $\{[(\mathrm{L}-\mathrm{H}) \mathrm{Cu}]\}^{+}$respectively. Examination of the mass of the two lower molecular ions shows that the ligand has depotonated in the gas phase (presumably the amine hydrogen atom). Clearly the trinuclear species is present but no direct ions corresponding to the octanuclear assembly are observed. Whether the lower molecular weight anions are due to fragmentation of the $\left[\mathrm{L}_{4} \mathrm{Cu}_{8}\left(\mathrm{SeO}_{3}\right)_{4}\right]^{8+}$ or whether $\left[\mathrm{L}_{2} \mathrm{Cu}_{3}\left(\mathrm{SeO}_{3}\right)\right]^{4+}$ is favoured in the gas phase is difficult to ascertain. ESI-MS experiments using different stoichiometries of ligand, metal and anion (that either favour the trinuclear or octanuclear species) does not change the ions observed but does change the ratios between them. Resultantly the ions observed in the ESI-MS studies may be a consequence of the formation of the lower nuclearity species in the gas phase; but it is also possible that the octanuclear species is only an artefact of the solid-state.

\subsection{Conclusions}

In the presence of spherical, trigonal planar, tetrahedral and octahedral anions the ligand $\mathrm{L}$, upon reaction with $\mathrm{Cu}^{2+}$, results in the formation of a trinuclear cryptand e.g. $\left[\mathrm{L}_{2} \mathrm{Cu}_{3} \text { (Anion) }\right]^{\mathrm{n}+}$ and this occurs even when the anions are not 
symmetrical (i.e. $\mathrm{S}_{2} \mathrm{O}_{3}{ }^{2-}$ ). However, with the trigonal pyramidal $\mathrm{SeO}_{3}{ }^{2-}$ anion an octanuclear assembly is formed and attributable to maximising both the number of coordination bonds and the hydrogen bonding interactions.

\section{Key Words}

Copper : Self-assembly : Anion : Cryptand : Tripodal

\section{Declaration of interest.}

There are no interests to declare.

\section{References}

1. For linear helicate assemblies see: J-M. Lehn, Supramolecular Chemistry, VCH, Weinheim, 1995; J.W. Steed, J.L. Atwood, Supramolecular Chemistry, John Wiley and Sons, Chichester, (2000); M.J. Hannon, L.J. Childs, Supramol. Chem. (2004) 167; M. Albrecht, Chem. Rev. 101 (2001) 3547; M. Albrecht, Chem. Soc. Rev. 27 (1998) 281; C. Piguet, G. Bernardinelli, G. Hopfgartner, Chem. Rev. 97 (1997) 2005; E.C. Constable, in Comprehensive Supramolecular Chemistry, vol. 9; Polynuclear Transition Metal Helicates, ed J.-P. Sauvage, Elsevier, Oxford, (1996) 213; Q.Z. Sun, Y. Bai, G.J. He, C.Y. Duan, Z.H. Lin, Q.J. Meng, Chem. Commun. (2006) 2777. M. Cantuel, F. Gumy, J.C.G. Bunzli, C. Piguet, Dalton Trans. (2006) 2647; M. Hutin, R. Frantz, J.R. Nitschke, Chem. Eur. J. 2006, 4077; C.R. Rice, S. Wörl, J.C. Jeffery, R.L. Paul, M.D. Ward, Chem. Commun. (2000) 1529.

2. For mesocate assemblies see: I. Janser, M. Albrecht, K. Hunger, S. Burk, K. Rissanen, Eur. J. Inorg. Chem. 2006, 244; S. D. Reid, C. Wilson, C. I. De Matteis, J. B. Love, Eur. J. Inorg. Chem. (2007) 5286; Z. Zhang, D. Dolphin, Chem. Commun. (2009) 6931; Z. Zhang, Y. Chen, D. Dolphin, Dalton Trans. 41 (2012) 4751; M. Martínez-Calvo, M. J. Romero, R. Pedrido, A. M. González-Noya, G. Zaragoza, M. R. Bermejo, Dalton Trans. 41 (2012) 13395; Z. Zhang, D. Dolphin, Inorg. Chem. 49 (2010) 11550; F. Cui, S. Li, C. Jia, J. S. Mathieson, L. Cronin, X.-J. Yang, B. Wu, Inorg. Chem. 51 (2012) 179. D. J Cooke, J. M. Cross, R. V. Fennessy, L. P. Harding, C. R. Rice, C. Slater, Chem. Commun. (2013) 7785; S. J. Allison, D. Cooke, F. S. Davidson, P. I. P. Elliott, R. A Faulkner, H. B. S. Griffiths, O. J. Harper, O. Hussain, P. J. Owen-Lynch, R. M. Phillips, C. R. Rice, S. L. Shepherd, R. T Wheelhouse, Angew. Chem. Int. Ed. 57 (2018) 9799.

3. For circular helicate assemblies see: B. Hasenknopf, J-M. Lehn, N. Boumediene, E. Leize, A. Van Dorsselaer, Angew. Chem. Int. Ed. 37 (1998) 3265. B. Hasenknopf, J-M. Lehn, N. Boumediene, A. Dupont-Gervais, A. Van Dorsselaer, B. Kneisel, D. Fenske, J. Am. Chem. Soc. 119 (1997) 10956; S. P. Argent, H. Adams, T. RiisJohannessen, J. C. Jeffery. L. P. Harding, O. Mamula, M. D. Ward, Inorg. Chem. 45 (2006) 3905; J. Hamblin, F. Tuna, S. Bunce, L. J. Childs, A. Jackson, W. Errington, N. W. Alcock, H. Nierengarten, A. V. Dorsselaer, E. LeizeWagner, M. J. Hannon, Chem. Eur. J. 13 (2007) 9286. Y. Pang, S. Cui, B. Li, J. Zhang, Y. Wang, H. Zhang, Inorg. Chem. 47 (2008) 10317; L. J. Childs, M. Pascu, A. J. Clarke, N. W. Alcock, M. J. Hannon, Chem. Eur. J. 10 (2004) 4291. L. J. Childs, N. W. Alcock, M. J. Hannon, Angew. Chem. Int. Ed. 41 (2002) 4244; A. P. Paneerselvam, S. S. Mishra, D. K. Chand, J. Chem. Sci. 130 (2018) 96.

4. For cage assemblies see: L-J. Chen, H-B. Yang, M. Shionoya, Chem. Soc. Rev. 46 (2017) 2555; G. Cecot, M. T. Doll, O. M. Planes, A. Ramorini, R. Scopelliti, F. Fadaei-Tirani, K. Severin, Eur. J. Inorg. Chem. (2019) 2972; R. Chakrabarty, P. S. Mukherjee, P. J. Stang, Chem. Rev. 111 (2011) 6810; P. W. V. Butler, P. E. Kruger, J. S. Ward, Chem. Commun. 55 (2019) 10304; J. S. Train, A. B. Wragg, A. J. Auty, A. J. Metherell, D. Chekulaev, C. G. P. Taylor, S. P. Argent, J. A. Weinstein, M. D. Ward, Inorg. Chem. 58 (2019) 2386. Y-Y. Zhang, W-X. Gao, L. Lin, G- 
X. Jin, Coord. Chem. Rev. 344 (2017) 323; S. Zarra, D. M. Wood, D. A. Roberts, J. R. Nitschke, Chem. Soc. Rev. 44 (2015) 419; M. Whitehead, S. Turega, A. Stephenson, C. A. Hunter, M. D. Ward, Chem. Sci. 4 (2013) 2744.

5. D. Yang, J. Zhao, X.-J. Yanga, B. Wu, Org. Chem. Front., 2018, 5, 662; R. Vilar, Angew. Chem. Int. Ed. 42 (2003) 1460.

6. B. Hasenknopf, J-M. Lehn, B. O. Kneisel, G. Baum, D. Fenske, Angew. Chem. Int. Ed. 35 (1996) 1838; B. Hasenknopf, J.-M. Lehn, N. Boumediene, A. Dupont-Gervais, A. Van Dorsselaer, B. Kneisel, D. Fenske, J. Am. Chem. Soc. 119 (1997) 1095.

7. B. Wang, Z. Zang, H. Wang, W. Dou, X. Tang, W. Liu, Y. Shao, J. Ma, Y. Li, and J. Zhou, Angew. Chem. Int. Ed. 52 (2013) 3756

8. C. S. Campos-Fernández, B. L. Schottel, H. T. Chifotides, J. K. Bera, J. Bacsa, J. M. Koomen, D. H. Russell and K. R. Dunbar, J. Am. Chem. Soc. 127 (2005) 12909.

9. F. Cui, S. Li, C. Jia, J. S. Mathieson, L. Cronin, X-J. Yang, and B. Wu, Inorg. Chem. 51 (2012) 179.

10. Q. Lin, L. Gao, B. Kauffmann, J. Zhang, C. Ma, D. Luo and Q. Gan, Chem. Commun. 54 (2018) 13447.

11. R. A. Faulkner, L. P. Harding, J. Higginson, C. R. Rice and C. Slater, Angew. Chem. Int. Ed. 53 (2014) 13540.

12. C. R. Rice, Coord. Chem. Rev. 250 (2006) 3190; P. A. Gale, E. N. W. Howe and X. Wu, Chem. 1 (2016) 351; P. Gale, J. Davis, R. Quesada, Chem. Soc. Rev. 46 (2017) 2497. P. Gale, C. Caltagirone, Chem. Soc. Rev. 44 (2015) 4212. N. Busschaert, C. Caltagirone, W. Van Rossom, P. A. Gale, Chem. Rev. 115 (2015) 8038. J. Hiscock, M. Sambrook, N. Wells, P. Gale, Chem. Sci. 6 (2015) 5680. R. A. Faulkner, N. J. Patmore, C. R. Rice and C. Slater, Chem. Commun. 54 (2018) 9159. A. S. Degtyarenko, E. B. Rusanov, A. Bauzá, A. Frontera, H. Krautscheid, A. N. Chernega, A. A. Mokhire and K. V. Domasevitch, Chem. Commun. 49 (2013) 9018. V. Amendola and L. Fabbrizzi, Chem. Commun. (2009) 513.

13. J-F. Ayme, J. E. Beves, C. J. Campbell, G. Gil-Ramírez, D. A. Leigh and A. J. Stephens, J. Am. Chem. Soc. 137 (2015) 9812.

14. C. R. Rice, C. Slater, R. A. Faulkner and R. L. Allan, Angew. Chem. Int. Ed. 57 (2018) 13071.

15. O. V. Dolomanov, L. J. Bourhis, R. J. Gildea, J. A. K. Howard and H. Puschmann, J. Appl. Cryst. 42 (2009) 339. 